( ) IGI Global. Xiao, Y., Hipel, K. W., \& Fang, L. (2015). Strategic Investigation of the Jackpine Mine Expansion Dispute in the Alberta Oil Sands. International Journal of Decision Support System Technology, 7(1), 50-62. https://doi.org/10.4018/ijdsst.2015010104

50 International Journal of Decision Support System Technology, 7(1), 50-62, January-March 2015

\title{
Strategic Investigation of the Jackpine Mine Expansion Dispute in the Alberta Oil Sands
}

\author{
Yi Xiao, Department of Systems Design Engineering, University of Waterloo, Waterloo, \\ Canada
}

Keith W. Hipel, Department of Systems Design Engineering, University of Waterloo, Waterloo, Canada \& Centre for International Governance Innovation, Waterloo, Canada

Liping Fang, Department of Mechanical and Industrial Engineering, Ryerson University, Toronto, Canada \& Department of Systems Design Engineering, University of Waterloo, Waterloo, Canada

\begin{abstract}
The Graph Model for Conflict Resolution (GMCR) methodology is employed to ascertain strategic insights into a serious conflict over environmental concerns connected to the expanded exploitation of oil sands at the Jackpine Mine Expansion project located in Alberta, Canada. In fact, the expansion of extracting bitumen from large tracts of oil sands in Alberta and its associated potential negative environmental impacts have received increasing attention at the global level. Accordingly, environmentally responsible extended mining of bitumen at the Jackpine site is urgently needed. Hence, the GMCR methodology and its associated decision support system GMCR II are utilized to systematically investigate the conflict of the Jackpine Mine Expansion project. The results imply that the Federal Government of Canada is more concerned about the economic benefits generated by the oil sands projects rather than environmental impacts. It is suggested that more effort should be devoted to the environment conservation by the government.
\end{abstract}

Keywords: $\quad$ Decision Support System, Development, Graph Model for Conflict Resolution, Jackpine Mine Expansion, Oil Sands

\section{INTRODUCTION}

The oil sands are one of the most controversial energy resources in Canada. They create great economic benefits but at the same time could cause significant environmental damage. They also foster short term versus long term economic scenarios, depending on which stakeholders are the key beneficiaries (Marceau \& Bowman, 2014). Internationally and within Canada, environmental issues have directly resulted in protest over the oil sands development in general and specifically at the Jackpine Mine Expansion project. The dispute commenced when Shell 
Canada intended not to fulfill its commitments with regard to the significant reduction of its greenhouse gas emissions.

To formally study the conflict of the Jackpine Mine Expansion dispute, the Graph Model for Conflict Resolution (GMCR) methodology is utilized. The dispute is divided into three phases because each phase involves different decision makers and corresponding options. Phase I commenced in 2007 when Shell was unwilling to implement its commitments of reducing greenhouse gas emissions, and ended when ajoint Federal Government of Canada and provincial Government of Alberta review panel was established in September 2011. Phase II ran from September 2011 until the joint review panel released a report in July 2013. Phase III started in July 2013 and concluded when the Federal Government issued a decision statement in December 2013.

This research constitutes an extension of the paper presented at the International Conference on Group Decision and Negotiation in 2014 (Xiao et al., 2014). Based on the conference paper, more detailed information about the modelling of the dispute is provided and more in depth analyses are presented.

\section{OIL SANDS DEVELOPMENT IN CANADA}

Canada has always been considered a country having vast natural resources, especially oil resources. It is believed that Canada holds the second largest potential reserves of oil resources in the world, following Saudi Arabia, and most of the oil resources are contained in the oil sands. The major parts of the Canadian oil sands deposits are located in Alberta, Canada. It is estimated that there is a potential of 173 billion barrels of bitumen that can be recovered from the Alberta oil sands, and they are primarily found in three main locations: Athabasca, Cold Lake and Peace River, as depicted in Figure 1 (AER, 2014).

In recent years, the oil sands projects in the Alberta have expanded rapidly. Considerable economic benefits have been generated from the development of oil sands projects. It is expected that oil sands activities could create a Gross Domestic Product (GDP) benefit of as much as $\$ 885$ billion, and a total government revenue of $\$ 123$ billion between 2000 and 2020 (Timilsina et al., 2005). It is also estimated about $\$ 25.2$ billion was invested in oil sands projects

Figure 1. Alberta oil sands areas (based on AER (2014))

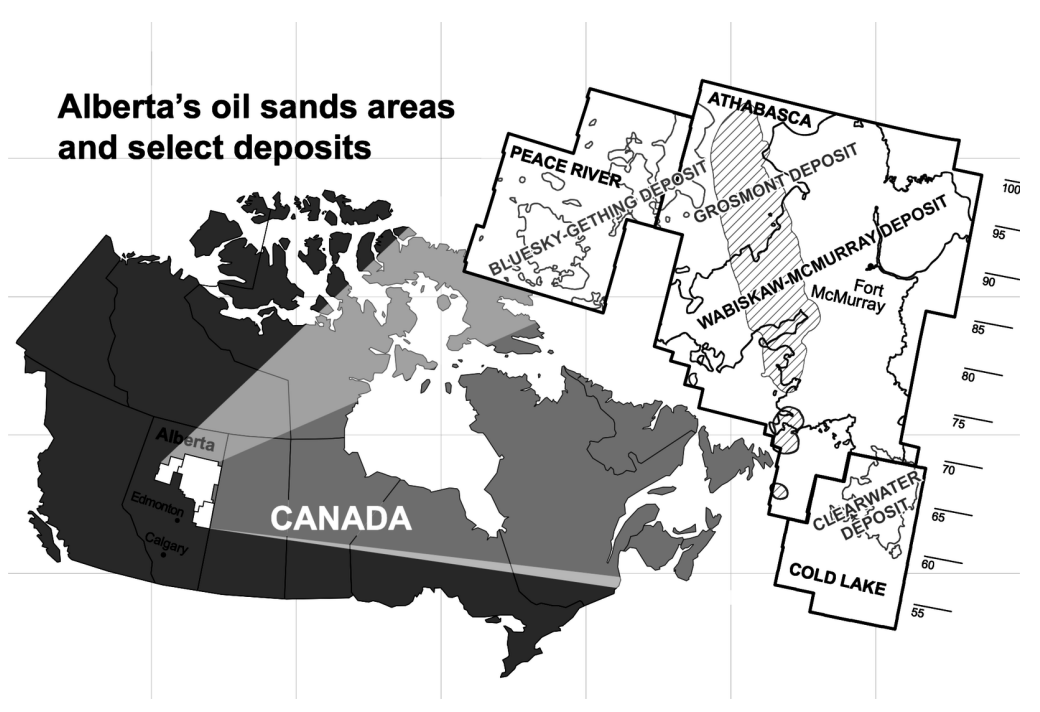

Copyright $(c)$ 2015, IGI Global. Copying or distributing in print or electronic forms without written permission of IGI Global is prohibited. 
in 2012, and about $\$ 159.5$ billion was invested in oil sands projects in Alberta from 2001 to 2012 (Alberta Energy, 2013).

Coupled with expansion are concerns with respect to detrimental impacts on the environment, both locally and internationally. For instance, the building of holding ponds holding toxic waste could contaminate rivers, lakes, and aquifers. Furthermore, the release of greenhouse gases caused by the mining and upgrading of bitumen from the oil sands could significantly increase. There is also the issue of the large quantities of water needed to extract, ship and upgrade bitumen. Finally, there is the criticism of long term economic benefits to Canadians are not being taken into account
(Marceau \& Bowman, 2014). The Jackpine Mine Expansion dispute is concerned with the release of increased greenhouse gases due to the expansion of the project by Shell.

\section{BACKGROUND OF THE JACKPINE MINE EXPANSION DISPUTE}

The Jackpine Mine Expansion project is an oil sands mining project located about $70 \mathrm{~km}$ north of Fort McMurray on the east side of the Athabasca River, and it extends to the north of the current Jackpine Mine project. The location map of the project can be seen in Figure 2.

Figure 2. Map of the project location (based on Shell Canada (2007))

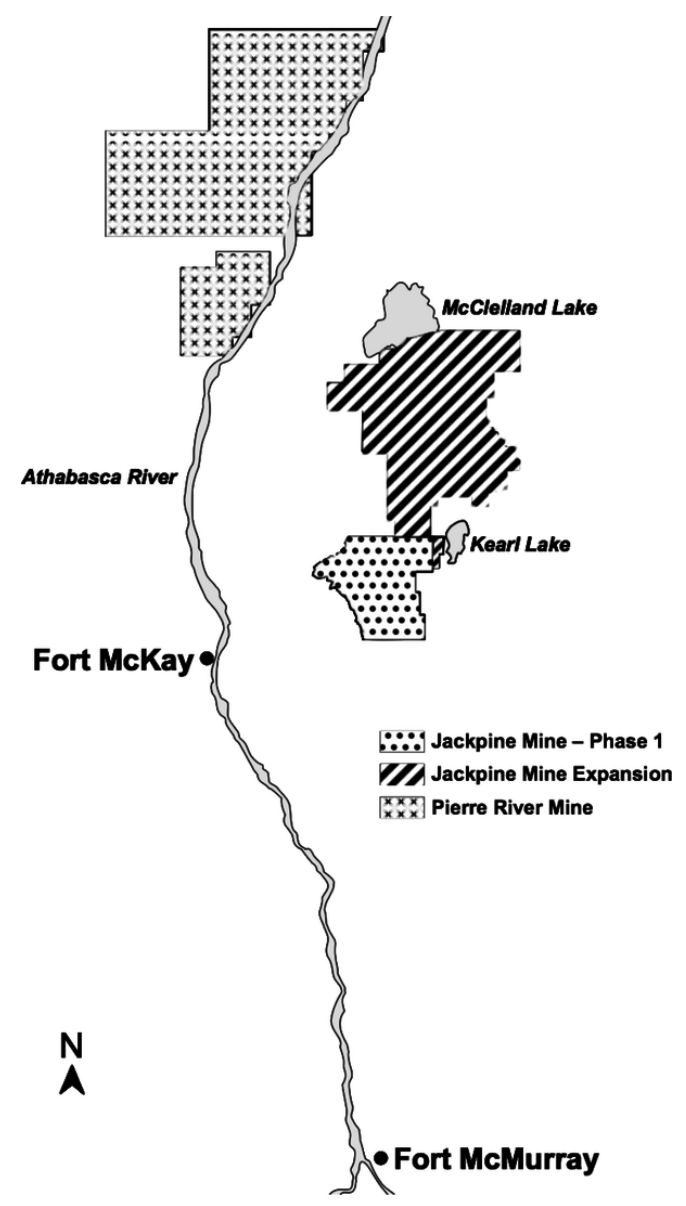


On May 31, 2002, Shell Canada submitted an application for the Jackpine Mine-Phase I (JMPI) project. The JMPI initiative received regulatory approval by the governments of Alberta and Canada in 2004, and began operations in August 2011 (Shell Canada, 2007, Christian, 2011). On September 18, 2003, Shell and the Oil Sands Environmental Coalition (OSEC), a non-governmental organization (NGO), reached a bilateral agreement which included commitments to significantly reduce greenhouse gas pollution from the JMPI project. OSEC believed that the approval of the JMPI project was assisted by this agreement (Pembina Institute, 2009a). In December 2007, Shell submitted an application for the Jackpine Mine Expansion (JPME) project which would increase the production by 100,000 barrels of bitumen per day. The JMPE project was approved in January, 2009.

During the period from November 2007 to January 2009, in written correspondence and face-to-face meetings, OSEC realized that Shell did not intend to fulfill its commitments; rather it planned to comply with future federal greenhouse gas $(\mathrm{GHG})$ regulatory requirements (Pembina Institute, 2009a). OSEC believed that even if Shell were to comply with the federal GHG reduction requirements, Shell's GHG pollution from these projects would increase by an estimated 900,000 tonnes without the commitments. OSEC was disappointed and decided to take action. On behalf of the OSEC, the Pembina Institute submitted a complaint to the Alberta Energy Resources Conservation Board(ERCB) and the Canadian Environmental Assessment Agency (CEAA) on April 7, 2009. In the complaint, OSEC requested a new public hearing regarding the approval of JPME project because Shell reneged on written agreements with OSEC (Pembina Institute, 2009b).

On September 20, 2011, a joint federal and provincial review panel was established, and a public hearing was conducted on October 29, 2012 in Fort McMurray, Alberta. Shell and OSEC both provided supplemental information to the panel. On July 9, 2013, the Joint Review Panel (JRP) released a report claiming that there would be significant adverse project effects on certain wildlife and vegetation, but these effects could be justified. The project was recommended for approval with a series of recommendations (CEAA, 2013a).

The Panel's report was taken into account when the Federal Government made a final decision. In particular, on December 6, 2013, the Federal Ministry of the Environment issued a decision statement declaring that the project might proceed in accordance with conditions set out in the statement (CEAA, 2013b). The Pembina Institute reacted to the decision on December 9, 2013, stating that it was disappointed about the decision (Pembina Institute, 2013). A lawsuit was filed to the Federal Court by the Athabasca Chipewyan First Nation in January 2014.

Based on the background investigation, it can be seen that the dispute started in 2007 when OSEC realized that Shell was not going to abide by its commitments. During the evolution of the dispute, decision makers and their options changed at different phases. As a result, it is reasonable to divide the dispute into three different phases, and each phase can be considered as a separate, but connected conflict model.

\section{MODELING AND ANALYSIS OF THE CONFLICT}

GMCR is a comprehensive and flexible methodology for modeling and analyzing strategic conflict (Fang et al., 1993; Kilgour \& Hipel, 2005; Hipel et al., 2013). This technique requires relatively less information to construct a model: decision makers (DMs), options and preferences.

A decision support system called GMCR II was developed to assist the modeling and analysis of a strategic conflict. The structure of the decision support system is depicted in Figure 3. The decision support system comprises three main components: a modeling subsystem, an output interpretation subsystem, and an analysis engine. The modeling subsystem is used to 
Figure 3. Structure of decision support system GMCR II (based on Fang et al. (2003a))

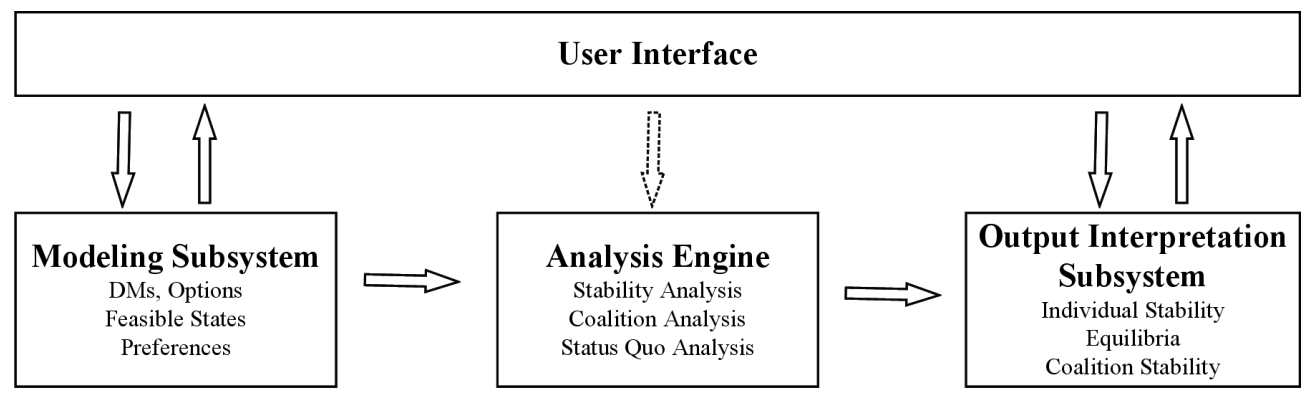

deal with the modeling information such as DMs, options, feasible states, and preference rankings. Next, the modeling information is conveyed to the analysis engine to calculate stability for each feasible state for every DM according to a solution concept. More analysis such as coalition analysis and status quo analysis can also be performed by the analysis engine. Finally, the output interpretation subsystem is utilized to present the computational results such as individual stability, equilibria, and coalition stability.

\subsection{Decision Makers and Options}

DMs in a conflict would seek their own benefits based on the resources available. For instance, in the JPME conflict, Shell intends to comply with the future federal greenhouse gas regulatory requirements rather than the commitments to OSEC. This is economically beneficial for Shell since the commitments require Shell to reduce more greenhouse gas emission. On the other hand, OSEC is trying to protect the environment from the expanding oil sands development. These two DMs are involved in all three phases of the conflict.

More specifically, for the JPME Phase I conflict, Shell and OSEC are two of the key DMs. In addition, ERCB is another main DM. ERCB, as an independent agency of the government of Alberta, is authorized to make decisions on applications for energy development, monitoring for compliance assurance, decommissioning of developments, and all other aspects of energy resources activities (AER, 2013). ERCB granted the regulatory approval for the project in January 2009. It should be noted that ERCB has been succeeded by the Alberta Energy Regulator (AER) since June 2013, but during Phase I, it was still ERCB that was in charge. Hence, ERCB is considered as a DM.

During Phase I, Shell has two options which are negotiate with OSEC to reach a new agreement or insist on complying with the federal greenhouse gas regulatory requirements. For OSEC, there are two choices that can be performed, including negotiate with Shell or request a public hearing. The option for ERCB would be whether to hold a public hearing or not.

Once ERCB decided to conduct a public hearing regarding the project, a Joint Federal and Provincial Review Panel was established. Subsequently, the conflict turned into Phase II. During Phase II, one of the main DMs changed to the Joint Review Panel (JRP) instead of ERCB. JRP is an independent body, mandated by the Federal Minister of the Environment and the Chairman of the Energy Resources Conservation Board, to assess the environmental effects of the proposed project and review the application (CEAA, 2013c). JRP's responsibility is to make a recommendation regarding the project. At this point in time, Shell had no choice but to persuade the JRP to approve the original project. OSEC was in the same situation but the difference was to convince JRP to reject the project. JRP would review the additional materials provided by Shell and OSEC, and 
make a recommendation to approve the project, modify the project, or reject the project.

After the JRP made a recommendation, a final decision should be made by the Federal Government. Then, the conflict turned into Phase III. During Phase III, the DMs changed to Shell, OSEC, and the Federal Government. Their options also changed. For the Federal Government, there are two options: 1) agree with the recommendation, and 2) reject the recommendation. Since JRP's recommendation was to modify the project, if the Federal Government rejected the recommendation, this means the project was rejected. For Shell, the only option would be to accept the decision or not. OSEC also has only one option which is to accept the decision or not. However, if OSEC prefers not to accept the decision, it will protest against the decision, and if OSEC accepts the decision, then there will be no protest. Therefore, the option for OSEC is given as "Protest" instead of "Accept".
The DMs and their options for the three phases of the JPME conflict are summarized in Table 1. A dash "_-" in the table means the corresponding DM is not involved in that phase.

\subsection{Feasible States}

An option means a possible action that a given DM may take. The selection of options under the control of a given DM forms a strategy. The combination of each DM's strategy constitutes a state. Changes in the selection of options by a given DM will cause the state to change accordingly. A conflict with $n$ options has $2^{n}$ states in total. However, not all states are possible to occur in reality, the infeasible states should be eliminated. There are four types of states that might be eliminated (Fraser \& Hipel, 1984): (1) logically infeasible states for a single player, (2) preferentially infeasible states for a single player, (3) logically infeasible states between players, (4) preferentially infeasible states be-

Table 1. Summary of decision makers and options in the JPME conflict

\begin{tabular}{|c|c|c|c|}
\hline DMs & Phase I & Phase II & Phase III \\
\hline \multirow{2}{*}{ Shell } & $\begin{array}{l}\text { 1. Comply with federal } \\
\text { requirements (Comply) }\end{array}$ & \multirow{2}{*}{$\begin{array}{l}\text { 1. Continue the project } \\
\text { (Continue) }\end{array}$} & \multirow{2}{*}{$\begin{array}{l}\text { 1. Accept the decision } \\
\text { (Accept) }\end{array}$} \\
\hline & $\begin{array}{l}\text { 2. Negotiate with OSEC } \\
\text { (Negotiate) }\end{array}$ & & \\
\hline \multirow{2}{*}{ OSEC } & $\begin{array}{l}\text { 3. Request public hearing } \\
\text { (Request) }\end{array}$ & \multirow{2}{*}{$\begin{array}{l}\text { 2.Against the project } \\
\text { (Against) }\end{array}$} & \multirow{2}{*}{ 2. Protest (Protest) } \\
\hline & $\begin{array}{l}\text { 4. Negotiate with Shell } \\
\text { (Negotiate) }\end{array}$ & & \\
\hline ERCB & $\begin{array}{l}\text { 5. Hold public hearing } \\
\text { (Hearing) }\end{array}$ & - & - \\
\hline \multirow{3}{*}{ JRP } & \multirow{3}{*}{-} & $\begin{array}{l}\text { 3. Approve the project } \\
\text { (Approve) }\end{array}$ & \multirow{3}{*}{-} \\
\hline & & $\begin{array}{l}\text { 4. Modify the project } \\
\text { (Modify) }\end{array}$ & \\
\hline & & $\begin{array}{l}\text { 5. Reject the project } \\
\text { (Reject) }\end{array}$ & \\
\hline \multirow{2}{*}{$\begin{array}{l}\text { Federal } \\
\text { Government }\end{array}$} & \multirow{2}{*}{ - } & \multirow{2}{*}{ - } & $\begin{array}{l}\text { 3. Agree with the } \\
\text { recommendation (Agree) }\end{array}$ \\
\hline & & & $\begin{array}{l}\text { 4. Reject the } \\
\text { recommendation (Reject) }\end{array}$ \\
\hline
\end{tabular}


tween players. For example, in Phase I, Shell will not choose its two options simultaneously, and must select at least one of its options. OSEC is the same. Moreover, ERCB will conduct a public hearing if and only if OSEC requests one. The elimination process leaves six feasible states in Phase I of the conflict, as shown in Table 2. In this table, the letter "Y" means the option is selected while " $\mathrm{N}$ " means the option is not chosen by the DM controlling it.

Similarly, the JRP can only select one of its options and must choose one from its three options in Phase II. The Federal Government must make a decision in Phase III. The feasible states for Phase II and Phase III after the elimination of infeasible states are presented in Tables 3 and 4, respectively.

\subsection{Preference Statements}

Preferences are an important aspect in a conflict study, and preferences construction is a very challenging task. There are many techniques including quantitative and non-quantitative

Table 2. Feasible states for Phase I

\begin{tabular}{|l|l|l|l|l|l|l|l|}
\hline \multicolumn{1}{|c|}{ DMs } & \multicolumn{1}{|c|}{ Options } & & & & & & \\
\hline \multirow{3}{*}{ Shell } & Comply & Y & N & Y & N & Y & N \\
\cline { 2 - 9 } & Negotiate & N & Y & N & Y & N & Y \\
\hline \multirow{2}{*}{ OSEC } & Request & Y & Y & N & N & Y & Y \\
\cline { 2 - 9 } & Negotiate & N & N & Y & Y & N & N \\
\hline \multirow{2}{*}{ ERCB } & Hearing & N & N & N & N & Y & Y \\
\hline State Number & & 1 & 2 & 3 & 4 & 5 & 6 \\
\hline
\end{tabular}

Table 3. Feasible states for Phase II

\begin{tabular}{|c|l|l|l|l|l|l|l|l|l|l|l|l|l|}
\hline DMs & Options & & & & & & & & & & & & \\
\hline Shell & Continue & $\mathrm{N}$ & $\mathrm{Y}$ & $\mathrm{N}$ & $\mathrm{Y}$ & $\mathrm{N}$ & $\mathrm{Y}$ & $\mathrm{N}$ & $\mathrm{Y}$ & $\mathrm{N}$ & $\mathrm{Y}$ & $\mathrm{N}$ & $\mathrm{Y}$ \\
\hline \multirow{2}{*}{ OSEC } & Against & $\mathrm{N}$ & $\mathrm{N}$ & $\mathrm{N}$ & $\mathrm{N}$ & $\mathrm{N}$ & $\mathrm{N}$ & $\mathrm{Y}$ & $\mathrm{Y}$ & $\mathrm{Y}$ & $\mathrm{Y}$ & $\mathrm{Y}$ & $\mathrm{Y}$ \\
\hline \multirow{3}{*}{ JRP } & Approve & $\mathrm{Y}$ & $\mathrm{Y}$ & $\mathrm{N}$ & $\mathrm{N}$ & $\mathrm{N}$ & $\mathrm{N}$ & $\mathrm{Y}$ & $\mathrm{Y}$ & $\mathrm{N}$ & $\mathrm{N}$ & $\mathrm{N}$ & $\mathrm{N}$ \\
\cline { 2 - 14 } & Modify & $\mathrm{N}$ & $\mathrm{N}$ & $\mathrm{Y}$ & $\mathrm{Y}$ & $\mathrm{N}$ & $\mathrm{N}$ & $\mathrm{N}$ & $\mathrm{N}$ & $\mathrm{Y}$ & $\mathrm{Y}$ & $\mathrm{N}$ & $\mathrm{N}$ \\
\cline { 2 - 14 } & Reject & $\mathrm{N}$ & $\mathrm{N}$ & $\mathrm{N}$ & $\mathrm{N}$ & $\mathrm{Y}$ & $\mathrm{Y}$ & $\mathrm{N}$ & $\mathrm{N}$ & $\mathrm{N}$ & $\mathrm{N}$ & $\mathrm{Y}$ & $\mathrm{Y}$ \\
\hline \multicolumn{2}{|l}{ State Number } & 1 & 2 & 3 & 4 & 5 & 6 & 7 & 8 & 9 & 10 & 11 & 12 \\
\hline
\end{tabular}

Table 4. Feasible states for Phase III

\begin{tabular}{|l|l|l|l|l|l|l|l|l|l|}
\hline \multicolumn{1}{|c|}{ DMs } & Options & & & & & & & & \\
\hline Shell & Accept & N & Y & N & Y & N & Y & N & Y \\
\hline OSEC & Protest & N & N & N & N & Y & Y & Y & Y \\
\hline \multirow{2}{*}{$\begin{array}{l}\text { Federal } \\
\text { Government }\end{array}$} & Agree & Y & Y & N & N & Y & Y & N & N \\
\cline { 2 - 11 } & Reject & N & N & Y & Y & N & N & Y & Y \\
\hline State Number & 1 & 2 & 3 & 4 & 5 & 6 & 7 & 8 \\
\hline
\end{tabular}


methods that can be used for preferences construction. When the information is very limited, non-quantitative methods are considered a better and easier way. Option prioritizing (Fang et al., 2003a) is one of the non-quantitative methods, and constitutes a realistic technique to employ for preferences construction. Under this technique, each DM has preference statements expressed in terms of options in the model, in which the preference statements are ranked from most important at the top to least important at the bottom. As is done in first order logic, a given preference statement can consist of any logical combination of options in which "and", "or", "if", and "if and only if" connectives can be used. A negative sign in front of an option number means the option is not selected. For example, in Phase I, Shell most prefers ERCB not to hold a public hearing, as indicated by -5 on the right side of Figure 4, next in importance is to comply with the federal requirements, as given by 1 in Figure 4. Shell's least important preference statement is to negotiate with OSEC, as indicated by 2 at the bottom of Figure 4 on the right. As obtained by using the option prioritization technique, Shell's preference ranking of states from most preferred on the left to least preferred on the right is: $(3,1,4,2,5,6)$. OSEC prefers to request a public hearing as being of highest importance because Shell insists not to implement its commitments with OSEC. Then, OSEC would like ERCB to convene a public hearing if OSEC requests one. OSEC would also like to negotiate if and only if Shell is willing to negotiate. OSEC's preference ranking of states is: $(5,6,1,2,4,3)$. ERCB's most preferred statement is that Shell and OSEC negotiate with each other. Next, it would like to hold a public hearing if and only if OSEC requests one. ERCB's preference ranking of states is: $(4,3,6,2,5,1)$.

Similarly, in Phase II, Shell would like to continue the project the most, next Shell would like JRP not to recommend to reject the project. The least preferred statement for Shell is that OSEC keeps against the project. Therefore, Shell's preference ranking of states is: $(2,8,4$, $10,6,12,1,7,3,9,5,11)$. On the other hand, OSEC most prefers to against the project, and would like Shell not continue. Then, OSEC would like JRP to reject the project. OSEC's preference ranking of states is: $(11,9,7,12$, $10,8,5,3,1,6,4,2)$. JRP most prefers not to reject the project if Shell continues to provide additional materials. Next, JRP would not approve the project because of the opposition from OSEC. The preference ranking of states for JRP is: $(10,4,3,9,2,5,1,11,8,7,6,12)$.

Figure 4. Preferences construction for Shell in Phase I using the option prioritizing technique

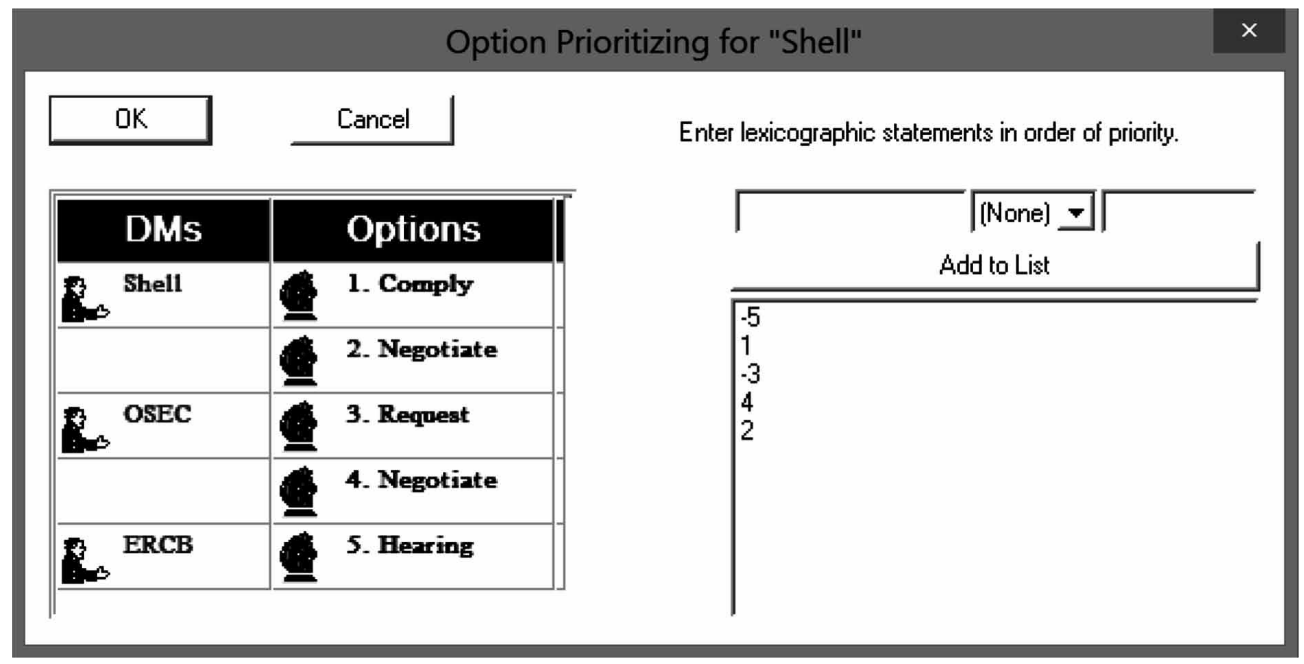


In Phase III, Shell most prefers that the Federal Government agrees with JRP's recommendation, and would like to accept the recommendation if and only if the government agrees. The least preferred statement for Shell is that OSEC not protest. As a result, the preference ranking of states for Shell is: $(2,6,1,5,3,7,4$, 8). Meanwhile, OSEC would like the Federal Government to reject the project. Then, OSEC prefers to protest if and only if the Federal Government agrees with JRP's recommendation. Therefore, OSEC's ranking of states is: $(4,3,7$, $8,5,6,2,1)$. For the Federal Government, the most preferred statement is that Shell accept the government's decision and OSEC not protest. Then the government would like to agree with JRP's recommendation. The preference ranking of states for the Federal Government is: $(2,4$, $1,3,6,8,5,7)$.

\subsection{Stability Analysis}

A state is stable for a DM if and only if the DM has no incentive to move away from the state. There are different types of stability definitions that are used to search for equilibria, including Nash stability (Nash, 1950, 1951), general metarationality (Howard, 1971), symmetric metarationality (Howard, 1971), sequential stability (Fraser \& Hipel, 1979, 1984), limitedmove stability (Kilgour et al., 1987; Fang et al., 1993), and non-myopic stability (Kilgour et al., 1987; Fang et al., 1993). The characteristics and descriptions of these solution concepts are summarized in Table 5. As can be seen in Table 5, Nash stability (R) has the lowest foresight while non-myopic (NM) has the highest, and the foresight level of limited-move stability $\left(L_{h}\right)$ depends on the parameter $h$. It is noted that foresight means how many moves and countermoves a DM can think ahead. For example, one DM only considers one move ahead by himself under Nash stability. While with limited-move stability, one can entertain $h$ moves and countermoves by the focal DM and the opponent. Under Nash stability, general metarationality (GMR), and symmetric metarationality (SMR), less information about the preferences is required than the other three types

Table 5. Solution concepts and behavioral characteristics (based on Hipel et al. (1997); Fang et al. (2003b))

\begin{tabular}{|l|l|l|l|}
\hline \multicolumn{1}{|c|}{ Solution Concepts } & Foresight & \multicolumn{1}{c|}{$\begin{array}{c}\text { Knowledge of } \\
\text { Preferences }\end{array}$} & \multicolumn{1}{c|}{ Description } \\
\hline $\begin{array}{l}\text { Nash Stability (R) } \\
\text { (Nash, 1950, 1951) }\end{array}$ & Low & Own & $\begin{array}{l}\text { DM cannot unilaterally move to a } \\
\text { more preferred state. }\end{array}$ \\
\hline $\begin{array}{l}\text { General Metarationality } \\
\text { (GMR) } \\
\text { (Howard, 1971) }\end{array}$ & Medium & Own & $\begin{array}{l}\text { All of DM's unilateral improvements } \\
\text { are sanctioned by subsequent } \\
\text { unilateral moves by others. }\end{array}$ \\
\hline $\begin{array}{l}\text { Symmetric Metarationality } \\
\text { (SMR) } \\
\text { (Howard, 1971) }\end{array}$ & Medium & Own & $\begin{array}{l}\text { All of DM's unilateral improvements } \\
\text { are still sanctioned even after a } \\
\text { possible response by the original DM. }\end{array}$ \\
\hline $\begin{array}{l}\text { Sequential Stability (SEQ) } \\
\text { (Fraser \& Hipel, 1979, 1984) }\end{array}$ & Medium & All & $\begin{array}{l}\text { All of DM's unilateral improvements } \\
\text { are sanctioned by subsequent } \\
\text { unilateral improvements by others. }\end{array}$ \\
\hline $\begin{array}{l}\text { Limited-move Stability }\left(L_{h}\right) \\
\text { (Kilgour et al., 1987; Fang et } \\
\text { al., 1993) }\end{array}$ & Variable & All & $\begin{array}{l}\text { All DMs are assumed to act optimally } \\
\text { and a fixed number of state transitions } \\
(h) \text { are specified. }\end{array}$ \\
\hline $\begin{array}{l}\text { Non-myopic Stability (NM) } \\
\text { (Kilgour et al., 1987; Fang et } \\
\text { al., 1993) }\end{array}$ & High & All & $\begin{array}{l}\text { Limiting case of limited-move stability } \\
\text { as the number of state transitions } \\
\text { increases to infinity. }\end{array}$ \\
\hline
\end{tabular}


of concepts, one DM only requires to know its own preferences.

A state that is stable for all DMs is called an equilibrium or resolution. An equilibrium provides a possible resolution to the conflict. The equilibria can be identified using the decision support system GMCR II (Hipel et al., 1997, 2008; Fang et al., 2003a, b). A screenshot of final equilibria for Phase I using GMCR II can be seen in Figure 5. DMs and their corresponding options are listed at the top left of the diagram, and at the bottom left is the list of solution concepts. If a state satisfies a particular solution concept, a checkmark is put at the corresponding intersection point.

According to GMCR II, as shown in Figure 5, there are two equilibria for Phase I: a weak equilibrium (state 2 ) and a strong equilibrium (state 5). A strong equilibrium satisfies all solution concepts listed in Table 5 for all DMs, and can be considered as a reliable solution for a decision making problem with a greater confidence. A weak equilibrium, on the other hand, only satisfies some solution concepts for all DMs. For instance, state 2 is not a Nash equilibrium, but is an equilibrium under other solution concepts listed in Table 5. Therefore, state 2 is referred to as a weak equilibrium. State 5 indicates that Shell chose to comply with the federal requirements, OSEC was disappointed and requested a new public hearing, and ERCB decided to conduct a public hearing. Similarly, the single equilibrium for Phase II (state 10) indicates that Shell preferred to continue the project while OSEC preferred to be against the project. JRP recommended a modification to the original project. In fact, these results were the actual situations that happened in September 2009 and July 2013, respectively.

The findings calculated by GMCR II indicate that there are two equilibria for Phase III. If the Federal Government rejects the project, Shell would not accept the decision while OSEC would be glad to see this situation. If the Federal Government approves the project, OESC would be against the decision. In this case, the final result would depend on the preference of the Federal Government. In fact, the government approved the project in reality, which means that the government preferred the latter situation to the former one. A historical evolution of the dispute is illustrated in Figure 6. The diagram shows each DM's response during each phase of the conflict.

\section{Figure 5. Equilibria for Phase I}

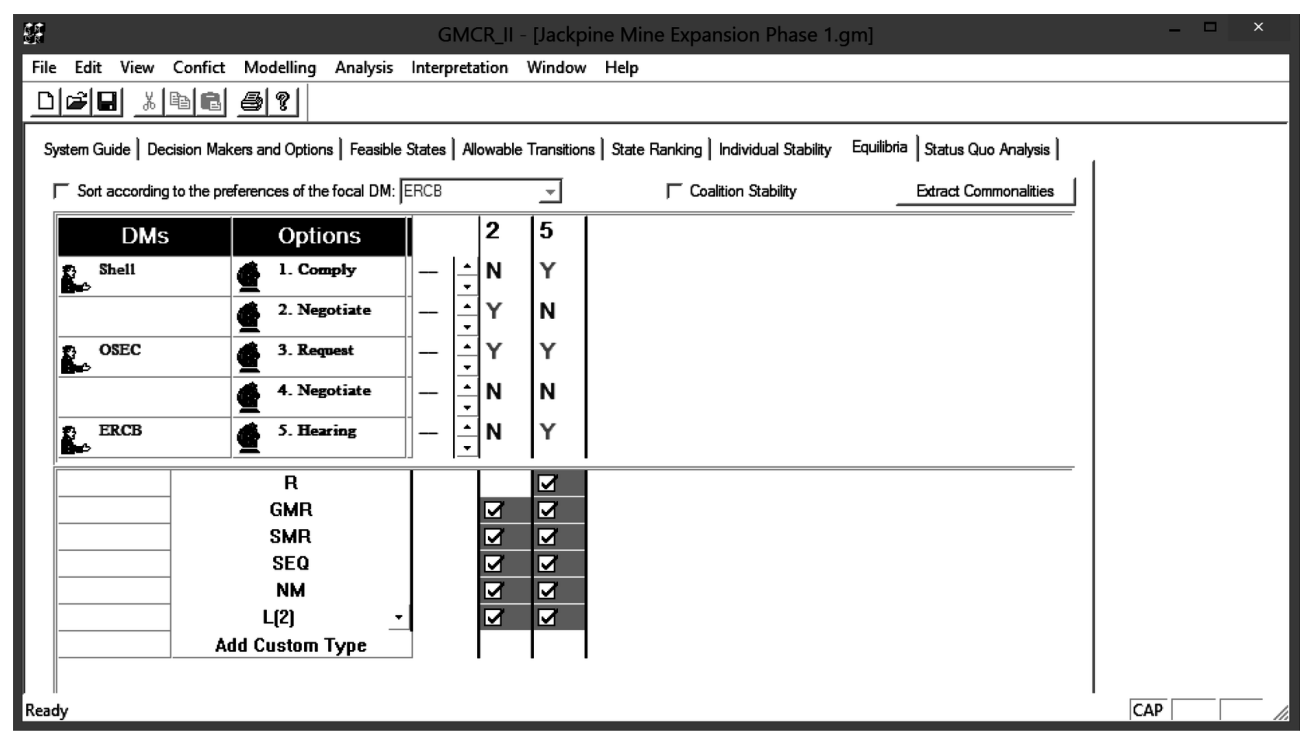


Figure 6. Historical evolution of the JPME conflict

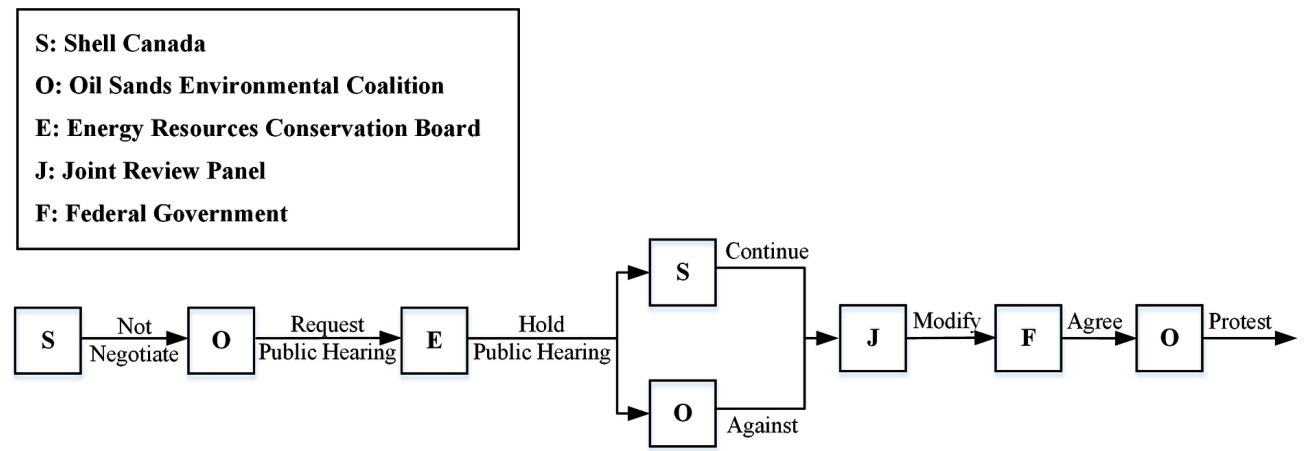

\subsection{Sensitivity Analysis}

A sensitivity analysis is a kind of investigation to determine how parameter changes in the model can influence the stability results. There are various types of sensitivity analyses in conflict analysis including preference changes, additions/deletions of DMs, option modifications, consideration of other kinds of human behavior, coalitions, misunderstandings, and entertainment of other modes to bargaining and negotiation (Fang et al., 2003b). As preference is an important part of a conflict analysis, preference change is one of the most crucial types of sensitivity analysis. In general, preference alternations can be done for more than one DM simultaneously, or for only one DM.

For example, if JRP cares more about the environmental issues, one would recommend not to approve the original project if there is opposition. If JRP cares more about economic benefits, then JRP would prefer to recommend approving the original project, and would recommend modifying the original project only if there is opposition. The preferences of the other DMs remain the same. The new preference statements can be utilized for ascertaining equilibria using GMCR II. The new equilibrium state becomes state 8 , in which Shell chooses to persuade JRP to approve the original project, and JRP recommends approving the original project although OSEC is against the project. A comparison of the initial equilibrium state and the new equilibrium state is shown in Table 6. According to Table 6 , the only difference between the initial equilibrium and new equilibrium is the recommendation made by JRP.

\section{INSIGHTS AND CONCLUSION}

Economic benefits and environmental damages are two important sides of the rapidly expanding oil sands projects. A balance between these two

Table 6. Comparison between initial and new equilibrium states in Phase II

\begin{tabular}{|c|c|c|}
\hline DMs & $\begin{array}{l}\text { Initial Modeling } \\
\quad \text { (State 10) }\end{array}$ & $\begin{array}{c}\text { Preference Change } \\
\text { (State 8) }\end{array}$ \\
\hline Shell & $\begin{array}{l}\text { Shell chooses to persuade JRP to approve } \\
\text { the project. }\end{array}$ & $\begin{array}{l}\text { Shell chooses to persuade JRP to } \\
\text { approve the project. }\end{array}$ \\
\hline OSEC & $\begin{array}{l}\text { Opposition is disappointed with the } \\
\text { decision, and chooses to oppose. }\end{array}$ & $\begin{array}{l}\text { Opposition is disappointed with the } \\
\text { decision, and chooses to oppose. }\end{array}$ \\
\hline JRP & $\begin{array}{l}\text { JRP recommends modifying the original } \\
\text { project. }\end{array}$ & $\begin{array}{l}\text { JRP recommends approving the original } \\
\text { project. }\end{array}$ \\
\hline
\end{tabular}


positions would significantly benefit having a more sustainable energy future. According to the results predicted by GMCR, one can presume that the Federal Government of Canada cares more about economic benefits than environmental impacts. The position of the government results in massive protests and complaints from environmental organizations and Aboriginal people. Hence, the government should make sure that the oil sands projects are developed in a responsible manner and more efforts are placed on the environmental stewardship.

Moreover, a sensitivity analysis for Phase II suggests that there exists a certain DM who holds the balance of power (JRP in this case). Changes in the preference of this DM would vary the equilibrium of the conflict, while changes in the preferences of other DMs (Shell and OSEC) would not change the equilibrium. This information can be useful in understanding the role of each DM in a multi-participant decision making problem.

\section{ACKNOWLEDGMENT}

The authors would like to express their gratitude to the anonymous reviewers for their helpful comments, as well as the Natural Sciences and Engineering Research Council (NSERC) of Canada and the National Natural Science Foundation of China (No. 71471087) for their financial support.

\section{REFERENCES}

AER (Alberta Energy Regulator). (2013). What We Do. Retrieved December 1, 2013, from http://www. aer.ca/about-aer/what-we-do

AER (Alberta Energy Regulator). (2014). Alberta's Energy Reserves 2013 and Supply/Demand Outlook 2014-2023. Retrieved October 10, 2014, from http:// www.aer.ca/documents/sts/ST98/ST98-2014.pdf

Alberta Energy. (2013). Talk about Oil Sands. Retrieved December 3, 2013, from http://www.energy. alberta.ca/OilSands/pdfs/FactSheet_OilSands.pdf
CEAA (Canadian Environmental Assessment Agency). (2013a). Report of the Joint Review Panel. Retrieved December 5, 2013, from http://www.ceaa. gc.ca/050/documents/p59540/90873E.pdf

CEAA (Canadian Environmental Assessment Agency). (2013b). Jackpine Mine Expansion Project - Release of Environmental Assessment Decision Statement. Retrieved December 12, 2013, from http://www.ceaa-acee.gc.ca/050/document-eng. cfm?document $=96783$

CEAA (Canadian Environmental Assessment Agency). (2013c). Public Notice Joint Review Panel Invites Public Comment for the Proposed Jackpine Mine Expansion Project. Retrieved December 5, 2013, from http://www.ceaa-acee.gc.ca/050/ document-eng.cfm?document $=52447$

Christian, C. (2011). Shell Opens Jackpine Mine. Retrieved October 13, 2014, from http://www. fortmcmurraytoday.com/2011/08/29/shell-opensjackpine-mine

Fang, L., Hipel, K. W., \& Kilgour, D. M. (1993). Interactive Decision Making: The Graph Model for Conflict Resolution. New York: Wiley.

Fang, L., Hipel, K. W., Kilgour, D. M., \& Peng, X. (2003a). A decision support system for interactive decision making-Part I: Model formulation. IEEE Transactions on Systems, Man and Cybernetics. Part C, Applications and Reviews, 33(1), 42-55. doi:10.1109/TSMCC.2003.809361

Fang, L., Hipel, K. W., Kilgour, D. M., \& Peng, X. (2003b). A decision support system for interactive decision making-Part II: Analysis and output interpretation. IEEE Transactions on Systems, Man and Cybernetics. Part C, Applications and Reviews, 33(1), 56-66. doi:10.1109/TSMCC.2003.809360

Fraser, N. M., \& Hipel, K. W. (1979). Solving complex conflicts. IEEE Transactions on Systems, Man, and Cybernetics, 9(12), 805-816. doi:10.1109/ TSMC.1979.4310131

Fraser, N. M., \& Hipel, K. W. (1984). Conflict Analysis: Models and Resolutions. New York: North-Holland.

Hipel, K. W., Fang, L., \& Kilgour, D. M. (2008). Decision support systems in water resources and environmental management. Journal of Hydrologic Engineering, 13(9), 761-770. doi:10.1061/ (ASCE)1084-0699(2008)13:9(761) 
Hipel, K. W., Fang, L., Quarda, T. B., \& Bristow, M. (2013). An introduction to the special issue on tackling challenging water resources problems in Canada: A systems approach. Canadian Water Resources Journal, 38(1), 3-11. doi:10.1080/0701 1784.2013.773643

Hipel, K. W., Kilgour, D.M., Fang, L., \& Peng, X. (1997). The decision support system GMCR in environmental conflict management. Applied Mathematics and Computation, 83(2), 117-152. doi:10.1016/S0096-3003(96)00170-1

Howard, N. (1971). Paradoxes of rationality: theory of metagames and political behavior. Cambridge, MA: MIT Press.

Kilgour, D. M., \& Hipel, K. W. (2005). The graph model for conflict resolution: Past, present, and future. Group Decision and Negotiation, 14(6), 441-460. doi:10.1007/s10726-005-9002-x

Kilgour, D. M., Hipel, K. W., \& Fang, L. (1987). The graph model for conflicts. Automatica, 23(1), 41-55. doi:10.1016/0005-1098(87)90117-8

Marceau, R. J., \& Bowman, C. W. (2014). Canada: Becoming a Sustainable Energy Powerhouse. Ottawa, Ontario, Canada: Canadian Academy of Engineering.

Nash, J. F. (1950). Equilibrium points in $n$-person games. Proceedings of the National Academy of Sciences of the United States of America, 36(1), 48-49. doi:10.1073/pnas.36.1.48 PMID:16588946
Nash, J. F. (1951). Non-cooperative games. The Annals of Mathematics, 54(2), 286-295. doi:10.2307/1969529

Pembina Institute. (2009a). Shell Breaks Global Warming Promise for Oil Sands Projects. Retrieved December 1, 2013, from http://www.pembina.org/ media-release/ 1808

Pembina Institute. (2009b). Letter to CEAA and ERCB Regarding Shell-OSEC agreement. Retrieved December 1, 2013, from http://www.pembina.org/ pub/1807

Pembina Institute. (2013). Pembina Reacts to Federal Approval of Shell Jackpine Mine Expansion. Retrieved December 12, 2013, from http://www. pembina.org/media-release/2509

Shell Canada. (2007). Jackpine Mine Expansion Project Description. Retrieved December 1, 2013, from http://s06.static-shell.com/content/dam/shellnew/local/country/can/downloads/pdf/aboutshell/ aosp/vol-1-jpme-projectdescription.pdf

Timilsina, G. R., LeBlanc, N., \& Walden, T. (2005). Economic Impacts of Alberta's Oil Sands. Calgary, Alberta, Canada: Canadian Energy Research Institute.

Xiao, Y., Hipel, K. W., \& Fang, L. (2014). Application of the graph model for conflict resolution to the Jackpine mine expansion dispute in the Alberta oil sands. In Proceedings of Group Decision and Negotiation (pp. 232-237). Toulouse, France: Toulouse University. 